\title{
Gastroprotective Value of Berries: Evidences from Methanolic Extracts of Morus nigra and Rubus niveus Fruits
}

\author{
Luciane Angela Nottar Nesello, ${ }^{1}$ Maria Luisa Maes Lima Beleza, ${ }^{2}$ Marihá Mariot, ${ }^{1}$ \\ Luísa Nathália Bolda Mariano, ${ }^{1,3}$ Priscila de Souza, ${ }^{3}$ Adriana Campos, ${ }^{1}$ \\ Valdir Cechinel-Filho, ${ }^{1,3}$ Sérgio Faloni Andrade, ${ }^{1,3}$ and Luísa Mota da Silva ${ }^{1,3}$ \\ ${ }^{1}$ Núcleo de Investigações Químico-Farmacêuticas (NIQFAR), Universidade do Vale do Itajaí (UNIVALI), Rua Uruguai, 458, Centro, \\ 88302-202 Itajaí, SC, Brazil \\ ${ }^{2}$ Graduação em Biomedicina, UNIVALI, Rua Uruguai, 458, Centro, 88302-202 Itajaí, SC, Brazil \\ ${ }^{3}$ Programa de Pós-Graduação em Ciências Farmacêuticas, UNIVALI, Rua Uruguai, 458, Centro, 88302-202 Itajaí, SC, Brazil
}

Correspondence should be addressed to Sérgio Faloni Andrade; faloni@univali.br

Received 28 April 2017; Accepted 22 August 2017; Published 20 September 2017

Academic Editor: Kazuhiko Uchiyama

Copyright (C) 2017 Luciane Angela Nottar Nesello et al. This is an open access article distributed under the Creative Commons Attribution License, which permits unrestricted use, distribution, and reproduction in any medium, provided the original work is properly cited.

\begin{abstract}
This study evaluated the gastroprotective value of the methanol extracts from fruits of Morus nigra L. (black mulberry (MEMN)) and Rubus niveus Thunb (raspberry (MERN)). The total phenolic compounds and flavonoids were measured, as well as the in vitro 2,2-diphenyl-1-picrylhydrazyl (DPPH) free radical scavenger activity. The gastroprotective effects of the extracts against $60 \%$ ethanol/0.3 M HCl were evaluated in mice. After that, the lipid hydroperoxides and reduced glutathione levels at ulcerated tissue were determined. The effects of extracts on $\mathrm{H}^{+} / \mathrm{K}^{+}$-ATPase activity were also verified. The extracts exhibited high contents of polyphenols; however, MERN presented 1.5-fold higher levels. The presence of flavonoids also was confirmed. In addition, MEMN $\left(\mathrm{IC}_{50}=13.74 \mu \mathrm{g} / \mathrm{mL}\right)$ and MERN $\left(\mathrm{IC}_{50}=14.97 \mu \mathrm{g} / \mathrm{mL}\right)$ scavenged DPPH radical. The MEMN reduced the ulcer area only at $300 \mathrm{mg} / \mathrm{kg}$ (p.o.) by $64.06 \%$. Interestingly, MERN decreased the ulcer area in a superior potency $\left(\mathrm{ED}_{50}=20.88 \mathrm{mg} / \mathrm{kg}\right)$, reducing the ulcer area by $81.86 \%$ at $300 \mathrm{mg} / \mathrm{kg}$, and increased the gastric mucin levels. The antioxidant effects of extracts were evidenced by reduced lipoperoxides and increased reduction of glutathione amount in the gastric mucosa. However, MEMN or MERN did not change the $\mathrm{H}^{+} / \mathrm{K}^{+}$-ATPase activity. These results confirm that $M$. nigra and $R$. niveus are berries with a gastroprotective value by strengthening of gastric protective factors.
\end{abstract}

\section{Introduction}

Gastric ulcer is a very frequent disease in the clinical practice and a challenge in the gastroenterology research [1-3]. This pathology is characterized by rupture of mucosal integrity in consequence of an imbalance between aggressive factors [acid gastric secretion, pepsin activity, and reactive oxygen species (ROS)] and the endogenous protective elements (mucus barrier, bicarbonate secretion, and adequate blood flow) of the gastric mucosa [4]. In addition, the occurrence of the gastric ulcer may be related to exogenous factors such as inadequate diet [5], alcohol consumption [6], prolonged use of nonsteroidal anti- inflammatory drugs (NSAIDs) [7], and Helicobacter pylori infection [8].

Currently, the antiulcer treatment can be performed with antacid drugs, such as proton pump inhibitors (PPIs) or antagonists of the type 2 histamine receptors. However, this therapy produces serious adverse effects, including osteoporotic fracture; renal damage; infection (pneumonia and Clostridium difficile infection); rhabdomyolysis; deficiencies of vitamin $\mathrm{B}_{12}$, magnesium, and iron; anemia; and thrombocytopenia [9], and is being associated with poor ulcer healing quality and in turn ulcer recurrence [10]. Therefore, alternative antiulcer therapies are required, and therapeutic resources from diet can be a relevant tool in this search. 
The berries from the Rubus genus (Rosaceae) are distributed worldwide [11], whereas the Morus genus (Moraceae) is found from temperate to subtropical regions [12]. The bioactive effects of these berries have been commonly related to their phenolic compounds [such as phenolic acids, flavonoids (anthocyanins and flavonols), and tannins] and ascorbic acid contents [13]. Therefore, the recognition of these fruits as promising functional foods and their value as phytotherapics is growing around the world. Indeed, based on the folk medicine, the Morus genus is listed by the Brazilian government as a plant species with promising potential in human health improvement [14].

In view of the above, the present study evaluated the gastroprotective activity of extracts obtained from fruits of the Morus nigra L. (black mulberries) and Rubus niveus Thunb (raspberries), assessing their antioxidant properties and effects on gastric mucin content, as well as on $\mathrm{H}^{+} / \mathrm{K}^{+}$ATPase activity. In addition, the levels of phenolic compounds and flavonoids in both extracts were quantified.

\section{Materials and Methods}

2.1. Plant Material and Obtaining Extracts. In order to obtain the extracts, $24.0 \mathrm{~g}$ of $M$. nigra (black mulberries) and $24.0 \mathrm{~g}$ of $R$. niveus (raspberries) fruits were commercially obtained, manually chopped, and subjected to a maceration process with methanol. Each plant sample was separately macerated with methanol in a solvent: solid ratio of $10: 1.5$, at $25^{\circ} \mathrm{C}$, by seven days in a sealed glassware, and protected from light [15]. After this period, the obtained materials were filtered and the solvent was removed under reduced pressure, obtaining the methanolic extract from fruits of M. nigra (MEMN, $1.44 \mathrm{~g}, 6.00 \%$ yield) and the methanolic extract from fruits of $R$. niveus (MERN, $1.73 \mathrm{~g}, 7.21 \%$ yield).

\subsection{Quantification of Polyphenol and Flavonoid Content.} Total phenolic compounds were quantitated using the Folin-Ciocalteu reagent [16]. The absorbance of the extract solution $(100-400 \mu \mathrm{g} / \mathrm{mL})$ was assessed at $750 \mathrm{~nm}$. The total concentration of phenolic substances was calculated using a tannic acid curve as a standard, and the results were expressed in tannic acid equivalents (TAE).

The quantification of flavonoid on extract solution $(100-400 \mu \mathrm{g} / \mathrm{mL})$ was performed using aluminum chloride methanol solution [17]. The absorbance was read at $425 \mathrm{~nm}$, and the flavonoid content was expressed as quercetin equivalents (QE) and calculated using a quercetin standard curve.

2.3. In Vitro 2,2-Diphenyl-1-picrylhydrazyl (DPPH) Free Radical Scavenger Activity. For the quantification of total antioxidant activity, the scavenger capability of MEMN $(0.01-1000 \mu \mathrm{g} / \mathrm{mL})$ and MERN $(0.01-1000 \mu \mathrm{g} / \mathrm{mL})$ against the stable free radical 2,2-diphenyl-1-picrylhydrazyl (DPPH, $40 \mu \mathrm{g} / \mathrm{mL}$ ) was evaluated [18]. The decrease in absorbance $(570 \mathrm{~nm})$ was measured after $15 \mathrm{~min}$. Samples of distilled water and ascorbic acid $(50 \mu \mathrm{g} / \mathrm{mL})$ were used as negative and positive controls, respectively.
2.4. Animals. Female Swiss mice (25-30 g) from the Central Animal Laboratory of the Universidade do Vale do Itajaí (UNIVALI) were housed in polypropylene cages at $22 \pm 2^{\circ} \mathrm{C}$ under $12 \mathrm{~h}$ light/dark cycle with access to food and water ad libitum. The animals were deprived of food 8 hours prior to the experiments. One adult albino rabbit (Oryctolagus cuniculus, $2 \mathrm{~kg}$ ) was used to determine the gastric activity of $\mathrm{H}^{+} / \mathrm{K}^{+}$-ATPase. All protocols were approved by the Institutional Animal Ethics Committee of the UNIVALI (CEUA/UNIVALI; approval number 005/14).

2.5. Acidified Ethanol-Induced Acute Gastric Ulcer. The mice were divided into different groups $(n=6)$ and pretreated orally with vehicle (water, $10 \mathrm{~mL} / \mathrm{kg}$ ), carbenoxolone (used as the positive control, $100 \mathrm{mg} / \mathrm{kg}$ ), MEMN (30$300 \mathrm{mg} / \mathrm{kg})$, or MERN (10-300 mg/kg); an ulcerogenic solution composed of $60 \%$ ethanol $/ 0.3 \mathrm{M} \mathrm{HCl}$ was orally given to the mice one hour after the pretreatments [19]. One hour after the administration of the injurious agent, the animals were euthanized in $\mathrm{CO}_{2}$ atmosphere, and then, the stomachs were removed, opened along the greater curvature, stretched on glass plates, and digitized. The EARP image analysis software carried out the analysis of the stomachs, in order to determine the gastric ulcer area $\left(\mathrm{mm}^{2}\right)$.

2.6. Histological and Histochemistry Analyses. The ethanol/ $\mathrm{HCl}$-ulcerated gastric tissue from all experimental groups were fixed in a solution composed of $85 \%$ alcohol, $10 \%$ formalin, and 5\% acetic acid, dehydrated, diaphanized, embedded in paraffin, and sectioned $(5 \mu \mathrm{m})$. The slices were deparaffinized, and a part of histological segments were stained using the hematoxylin and eosin technique to observe histological changes in tunics of gastric tissue. The remaining portion of the deparaffinized segments was employed in histochemistry analysis to measure the amount of gastric mucin, using Schiff's Periodic Acid method [18]. The software Image ${ }^{\circledR}$ was used to quantify the gastric mucin.

2.7. Preparation of Subcellular Fraction. The ulcerated tissues from an ethanol/HCl-induced ulcer model were homogenized with $200 \mathrm{mM}$ phosphate buffer (pH6.5), and this homogenate was used in the quantification of lipoperoxides $(\mathrm{LOOH})$ and reduced glutathione (GSH) levels.

2.8. $\mathrm{LOOH}$ and GSH Measurements. The LOOH in the ethanol/HCl-ulcerated gastric mucosa was measured [20]. In microtubes, $100 \mu \mathrm{L}$ of the homogenate obtained with the ulcerated tissue was added to equal volume of methanol, mixed, and centrifuged at $9000 \times \mathrm{g}$ for $20 \mathrm{~min}$ at $4^{\circ} \mathrm{C}$. After, $30 \mu \mathrm{L}$ of the supernatant was added to $270 \mu \mathrm{L}$ of reaction medium [ $4 \mathrm{mM}$ butylated hydroxytoluene (BHT), $250 \mathrm{mM}$ $\mathrm{FeSO}_{4}, 25 \mathrm{mM} \mathrm{H}_{2} \mathrm{SO}_{4}$, and $100 \mathrm{mM}$ xylenol orange], solubilized in methanol, and incubated for 30 minutes at $25^{\circ} \mathrm{C}$. After that, the absorbance of reaction mixture was read at $560 \mathrm{~nm}$ and the concentration of LOOH was determined for each $1 \mathrm{mg}$ of protein using the extinction coefficient of $43.6 / \mathrm{M} / \mathrm{cm}$ for $\mathrm{H}_{2} \mathrm{O}_{2}$, cumene hydroperoxide, or butyl hydroperoxide. The results were presented as $\mathrm{mmol} / \mathrm{mg}$ of tissue. 
The GSH quantification was performed in $50 \mu \mathrm{L}$ of the gastric homogenate deproteinized with $40 \mu \mathrm{L}$ of $12.5 \%$ trichloroacetic acid. The samples were centrifuged for $20 \mathrm{~min}$ at $900 \times \mathrm{g}$ at $4^{\circ} \mathrm{C}$, and subsequently, a $10 \mu \mathrm{L}$ aliquot of the supernatant was added to $290 \mu \mathrm{L}$ of $0.4 \mathrm{M}$ TRIS buffer solution ( $\mathrm{pH} 8.9$ ). For the reaction to be initiated, $5 \mu \mathrm{L}$ of 5,5'-dithiobis-2-nitrobenzoic acid $(1 \mathrm{mM})$ was added to each sample 15 minutes before the spectrophotometric reading at $415 \mathrm{~nm}$. The individual values were interpolated in a GSH standard curve, with values expressed in $\mu \mathrm{g} / \mathrm{mg}$ tissue [21].

2.9. $\mathrm{H}^{+} / \mathrm{K}^{+}$-ATPase Activity. The gastric mucosa of a rabbit was employed for the isolation of the gastric microsomal portion [22]. The gastric mucosa were collected and processed to obtain a homogenate. The $\mathrm{H}^{+} / \mathrm{K}^{+}$-ATPase isolation was performed by ultracentrifugation followed by a separation gradient. Then, $100 \mu \mathrm{g}$ of $\mathrm{H}^{+} / \mathrm{K}^{+}$-ATPase isolated was incubated with the vehicle (10\% DMSO), MEMN (1-100 $\mu \mathrm{g} / \mathrm{mL})$, MERN $(1-100 \mu \mathrm{g} / \mathrm{mL})$, ouabain $(72.8 \mu \mathrm{g} / \mathrm{mL}$, an inhibitor of $\mathrm{Na}^{+} / \mathrm{K}^{+}$-ATPase), or omeprazole $\left(34.5 \mu \mathrm{g} / \mathrm{mL}\right.$, an $\mathrm{H}^{+} / \mathrm{K}^{+}$ATPase inhibitor). The incubation period was $20 \mathrm{~min}$ in the presence of the reaction mixture $[50 \mathrm{mM}$ Tris- $\mathrm{HCl}(\mathrm{pH} 7.4)$, $20 \mathrm{mM} \mathrm{KCl}$, and $\left.2.5 \mathrm{mM} \mathrm{MgCl}_{2}\right]$. After this period, adenosine triphosphate was added and the samples were incubated at $37^{\circ} \mathrm{C}$ for $10 \mathrm{~min}$. The $\mathrm{H}^{+} / \mathrm{K}^{+}$-ATPase activity was calculated using the molar extinction coefficient of the inorganic phosphate $(\mathrm{iP})(\varepsilon=11,000 / \mathrm{M} \cdot \mathrm{cm})$ and expressed in $\mu \mathrm{M} \mathrm{iP} / \mathrm{mg}$ protein/minute [23].

2.10. Statistical Analysis. The data were analyzed by the statistical program GraphPad Prism ${ }^{\circledR} 5.0$ and represented as the means \pm SEM, and the differences between the means were determined through one-way analysis of variance (ANOVA) followed by Bonferroni's test. In all experiments, $p<0.05$ was adopted as significant.

\section{Results and Discussion}

Berries are important sources of a variety of bioactive compounds, which can present beneficial effects to human health [24]. Among these nutraceuticals, the polyphenols and flavonoids have justified the pharmacological effects of berries [25-30]. Most of studies on the beneficial effects of berries are focused on cardiovascular disorders, advancing ageinduced oxidative stress, inflammatory responses, diverse degenerative diseases, and cancer [31-34], and few studies reported their antiulcer effects [35-37]. Therefore, the gastroprotective effects of fruits from $M$. nigra and $R$. niveus are described for the first time in this study.

Methanol is an appropriate solvent to extract polyphenols from M. nigra fruits [38], and for this reason, this solvent was employed to obtain the extracts used in our study. Indeed, both extracts demonstrated high contents of polyphenols and flavonoids, as demonstrated in Table 1. The recognition that the intake of dietary polyphenols in the human diet or their supplementation parallel to conventional treatment can result in a safe and effective management of peptic ulcer is growing [39]. Regarding the flavonoids, these
TABLE 1: Total phenolic compound and flavonoid amount in methanolic extract from Rubus niveus fruits (MENR) and in methanolic extract from Morus nigra fruits (MEMN).

\begin{tabular}{ccc}
\hline Extract & Total phenolic compounds & Total flavonoids \\
\hline MERN $(\mu \mathrm{g} / \mathrm{mL})$ & TAE \pm SEM & QE \pm SEM \\
100 & $59.50 \pm 2.41$ & $0.23 \pm 0.04$ \\
150 & $93.06 \pm 1.78$ & $0.35 \pm 0.01$ \\
200 & $132.96 \pm 7.49$ & $0.41 \pm 0.02$ \\
MEMN $(\mu \mathrm{g} / \mathrm{mL})$ & TAE \pm SEM & QE \pm SEM \\
100 & $44.79 \pm 1.22$ & $0.30 \pm 0.21$ \\
150 & $60.51 \pm 6.71$ & $0.48 \pm 0.04$ \\
200 & $88.63 \pm 6.02$ & $0.60 \pm 0.03$ \\
\hline
\end{tabular}

The results are expressed as mean \pm SEM of tannic acid equivalents (TAE) and quercetin equivalents (QE) in $\mu \mathrm{g} / \mathrm{mL}$.

secondary metabolites display a wide range of pharmacological properties in the gastroenterology, acting as antisecretory, cytoprotector, and antioxidant compounds [19, 40-42].

It is well known that phenolic compounds, which were quantified in MEMN and MERN, have high antioxidant activity [43]. Thus, the free radical scavenger activity of the extracts was measured, and the half-maximal inhibitory concentration $\left(\mathrm{IC}_{50}\right.$ ) of MEMN and MERN in the DPPH assay was $13.74 \mu \mathrm{g} / \mathrm{mL}\left(\operatorname{logIC}{ }_{50}=1.138\right)$ and $14.97 \mu \mathrm{g} / \mathrm{mL}$ $\left(\operatorname{logIC} C_{50}=1.170\right)$, respectively, as shown in Figures $1(\mathrm{a})$ and 1(b). Similarly, a stronger scavenger activity was described for a sugar-free methanolic extract obtained from $M$. nigra fruits [44], and an in vitro antioxidant activity of methanol extracts obtained from $R$. niveus was already verified $[45,46]$.

Several studies have described the involvement of oxidative stress in the pathogenesis of gastric lesions and have pointed out that redox signaling regulates several processes in the gastrointestinal epithelium [47]. In this context, the intake of antioxidants like nutraceuticals from berries may afford beneficial effects in attenuating the formation of the gastric lesions. The ethanol increases oxygen reactive species (ROS) generation, reduces the mucus protective layer, and in consequence promotes modification in gastric cellular homeostasis leading to severe damage to the gastric mucosa [48]. As shown in Figure 2(a), the MEMN presented a capacity of defense of the gastric mucosa against the acidified ethanol only at $300 \mathrm{mg} / \mathrm{kg}$ (p.o.), reducing by $64.06 \%$ the ulcer area, when compared with vehicle $\left(92.10 \pm 3.51 \mathrm{~mm}^{2}\right)$. Interestingly, as shown in Figure 2(b), the MERN presented a great gastroprotective potency in this same experimental model reaching a half-maximal effective dose $\left(\mathrm{ED}_{50}\right)$ of $20.88 \mathrm{mg} / \mathrm{kg}\left(\operatorname{logED_{50}}=0.057\right)$. As expected, the oral treatment with carbenoxolone $(100 \mathrm{mg} / \mathrm{kg})$, used as the positive control, also reduced the ulcer area (Figures $2(\mathrm{a})$ and 2(b)).

These findings introduce $M$. nigra and mainly $R$. niveus as a favorable source for antiulcer components, and it is important to emphasize that the potent gastroprotective effect of MERN may be related to its high polyphenol levels, since the amount of these compounds in its extract was at least 1.5-fold higher when compared to MEMN values. However, given the previous knowledge about the anti-inflammatory properties of M. nigra [49], the gastroprotective effect of MEMN 


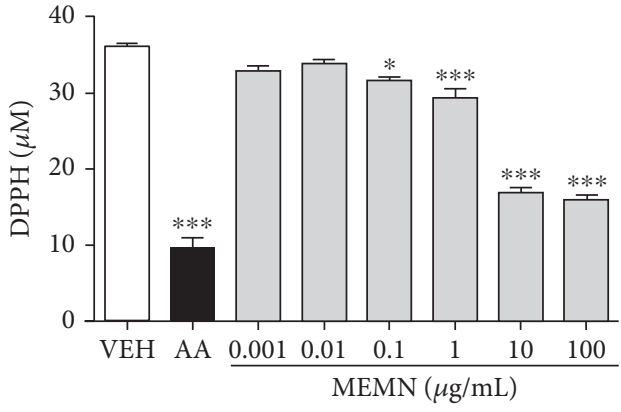

(a)

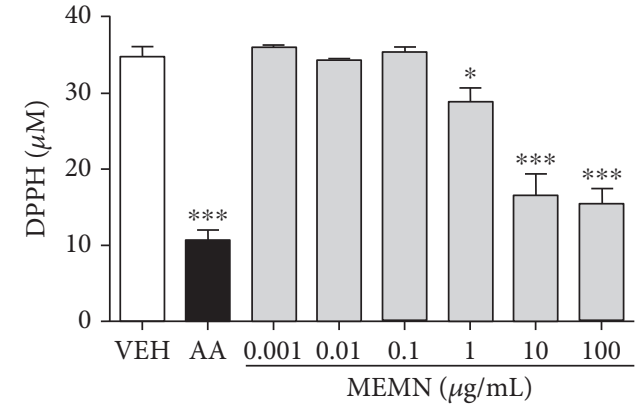

(b)

Figure 1: In vitro effects of (a) MEMN or (b) MERN $(0.001-100 \mu \mathrm{g} / \mathrm{mL})$ to scavenge the free radical DPPH. AA: ascorbic acid (50 $\mu \mathrm{g} / \mathrm{mL})$; VEH: vehicle (distilled water). The results are expressed as mean \pm SEM, in triplicated experiments. Statistical comparison was performed using one-way analysis of variance (ANOVA) followed by Bonferroni's test. ${ }^{*} p<0.05$ and ${ }^{* * *} p<0.001$ versus vehicle group.

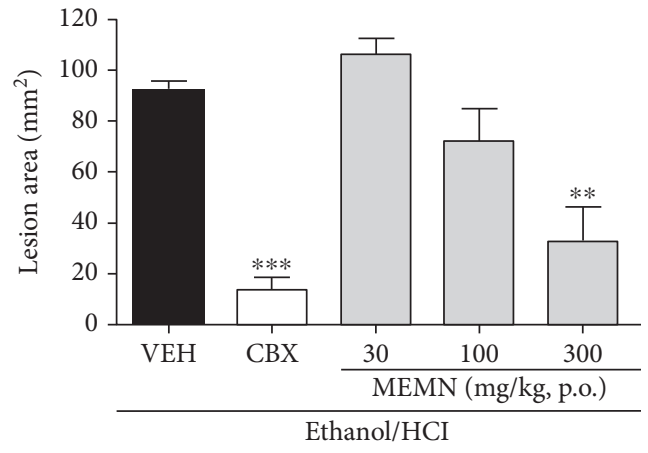

(a)

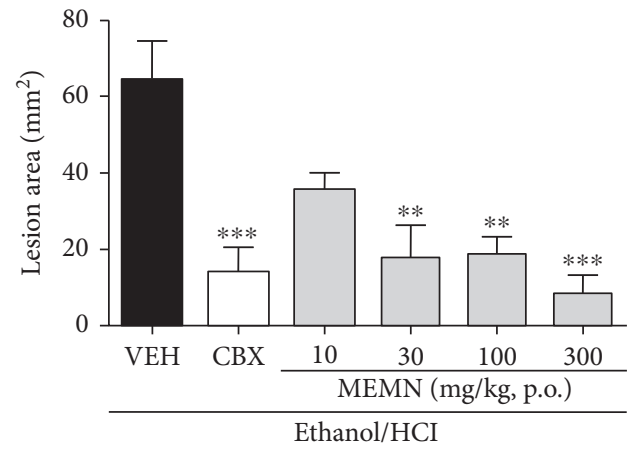

(b)

FIgURE 2: Gastroprotective effects of (a) MEMN (30-300 mg/kg, p.o.) or (b) MERN (10-300 mg/kg, p.o.) on acidified ethanolinduced gastric ulcers in mice. CBX: carbenoxolone $(100 \mathrm{mg} / \mathrm{kg}$, p.o.); VEH: vehicle $(10 \mathrm{~mL} / \mathrm{kg}$, p.o.). The results are expressed as mean \pm SEM $(n=6)$. Statistical comparison was performed using one-way analysis of variance (ANOVA) followed by Bonferroni's test. ${ }^{* *} p<0.01$ and ${ }^{* * *} p<0.001$ versus vehicle group.

described herein places this berry in an interesting position because most anti-inflammatory drugs do not have a good gastric tolerance and many of them are harmful agents to the gastric mucosa.

Representative macroscopic and microscopic images from the gastroprotective effect of both extracts are shown in Figures 3(a) and 3(b), respectively. Therefore, the gastroprotective effect of MEMN and MERN was confirmed by the decrease in the degree of epithelial damage evoked by acidified ethanol intake (Figure 3(b)). In parallel, the oral administration of MERN (100 or $300 \mathrm{mg} / \mathrm{kg}$ ), but not of MEMN (300 mg/kg), also increased the mucin staining in the gastric mucosa (Figures 4(a) and 4(b)). The structural and functional integrity of the gastric tissues is maintained by the equilibrium between aggressive and protective factors; the mucus-buffer-phospholipid layer is a preepithelial barrier and remains a crucial mucosal protection [50]. Because mucins are pivotal glycoproteins present in this barrier, it is possible to infer that the gastroprotective effects of MEMN and MERN are mediated by the luminal protection favoring. Figure 4(a) shows representative images from mucin staining from all experimental groups.
It is well established that the gastric tissue damage promoted by ethanol is directly related to the formation of ROS, resulting in decreased levels of GSH and antioxidant enzymes. The GSH is an important cellular antioxidant and has different functions, such as the ability to scavenge ROS in parallel acting in the prevention of ROS formation [51]. As shown in Figure 5, the levels of GSH in the vehicle-treated acidified ethanol-ulcerated stomach were decreased by $50.43 \%$. However, the treatment with MEMN $(300 \mathrm{mg} / \mathrm{kg}$, Figure 5(a)) or with $\operatorname{MERN}(30,100$, and $300 \mathrm{mg} / \mathrm{kg}$, Figure 5(b)) was both able to prevent the GSH depletion, indicating that the restoration of the tissue homeostasis promoted by these extracts was mediated by the improvement in the antioxidant capacity of the gastric mucosa.

An important marker of oxidative stress in tissues is the lipid peroxidation, including in the gastrointestinal tract [52]. As expected, increased levels of gastric $\mathrm{LOOH}$ were confirmed in the ulcerated group treated with vehicle $(29.57 \pm 2.99 \mathrm{mmol} / \mathrm{mg}$ of tissue). On the other hand, the MEMN (300 mg/kg, Figure 5(c)) promoted the partial reduction of it, similar to the MERN at doses of 100 and $300 \mathrm{mg} / \mathrm{kg}$ (Figure 5(d)). Given these data, the hypothesis 


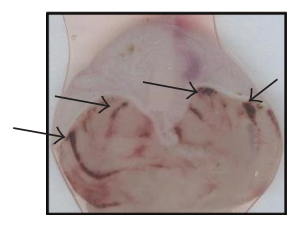

VEH

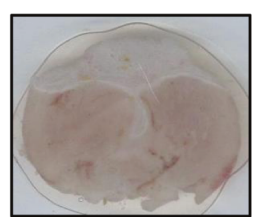

CBX

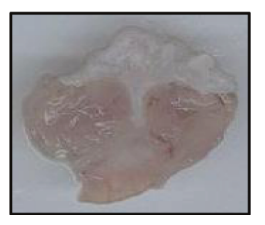

300

\section{$\operatorname{MEMN}(\mathrm{mg} / \mathrm{kg})$}

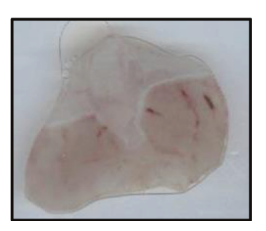

30

\begin{tabular}{ccc}
30 & 100 & 300 \\
\hline & MERN $(\mathrm{mg} / \mathrm{kg})$
\end{tabular}

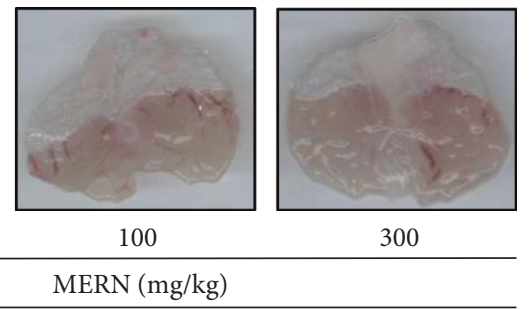

Ethanol/HCl

(a)

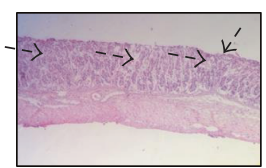

VEH

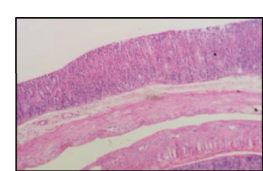

CBX

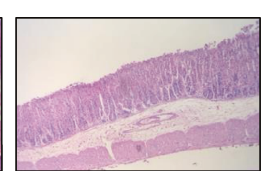

300

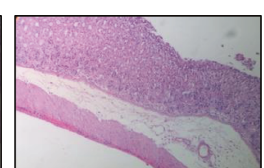

30

MEMN (mg/kg)

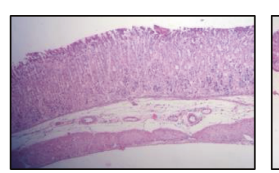

100

$\operatorname{MERN}(\mathrm{mg} / \mathrm{kg})$

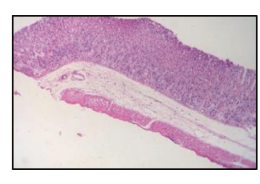

300

\section{Ethanol/HCl}

(b)

FIgURE 3: Macroscopic (a) and microscopic (b) representative images of the gastroprotective effects of MEMN and MERN on acidified ethanol-induced gastric ulcers in mice. The mice were orally treated with vehicle (water, $10 \mathrm{~mL} / \mathrm{kg})$, carbenoxolone (100 mg/kg), $\mathrm{MEMN}$ $(300 \mathrm{mg} / \mathrm{kg})$, or MEMN (30-300 mg/kg) 1 hour prior to acidified ethanol administration. The black arrows indicate the site of injury and the dotted black arrows show the glandular damage on the gastric mucosa. Histological section was increased by 100x.

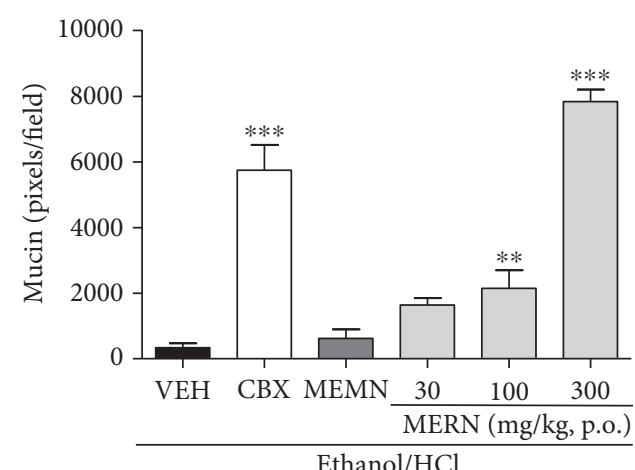

(a)

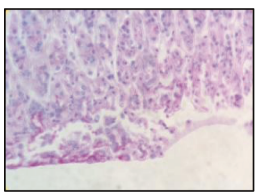

VEH

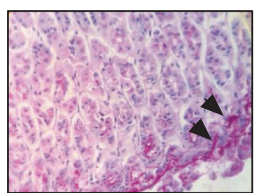

CBX

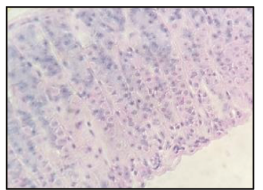

300

$\operatorname{MEMN}(\mathrm{mg} / \mathrm{kg})$

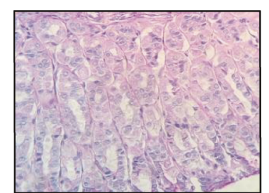

30

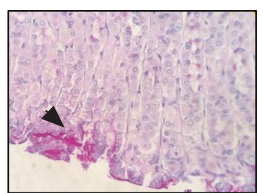

100

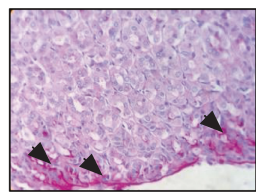

300

Ethanol/HCl

(b)

FIGURE 4: Effects of MEMN and MERN on histochemistry staining for mucin-like glycoproteins in the acidified ethanol-ulcerated gastric mucosa. (a) Representative images from groups treated with vehicle (water, $10 \mathrm{~mL} / \mathrm{kg}$ ), carbenoxolone (100 mg/kg), MEMN (300 mg/kg), or MERN (30-300 mg/kg). (b) Quantification of mucin staining with results expressed as mean \pm SEM $(n=6)$. Statistical comparison was performed using one-way analysis of variance (ANOVA) followed by Bonferroni's test. ${ }^{* *} p<0.01$ and ${ }^{* * *} p<0.001$ versus vehicle group. The arrows indicate the mucin-positive staining by 400x of magnification.

that both extracts can reduce the oxidative stress involved in the genesis of gastric injury induced by acidic ethanol is strengthened. Corroborating our findings, the inhibitory effects of a methanolic extract from fruits of M. nigra on the lipid peroxidation at the liver of rats were already described [53]. 


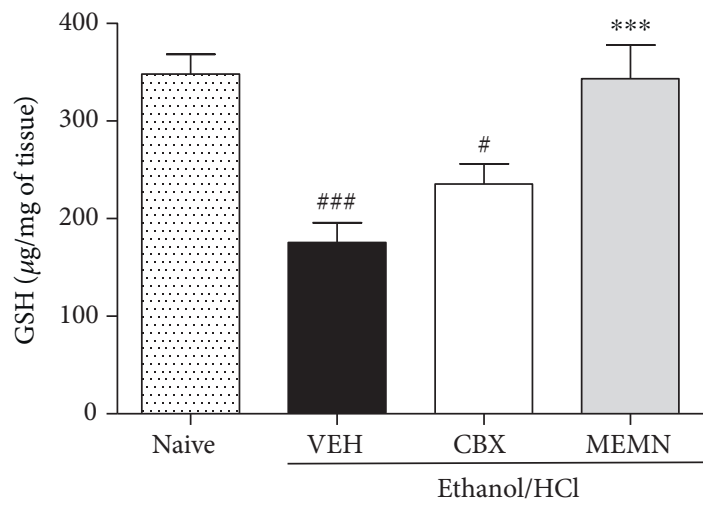

(a)

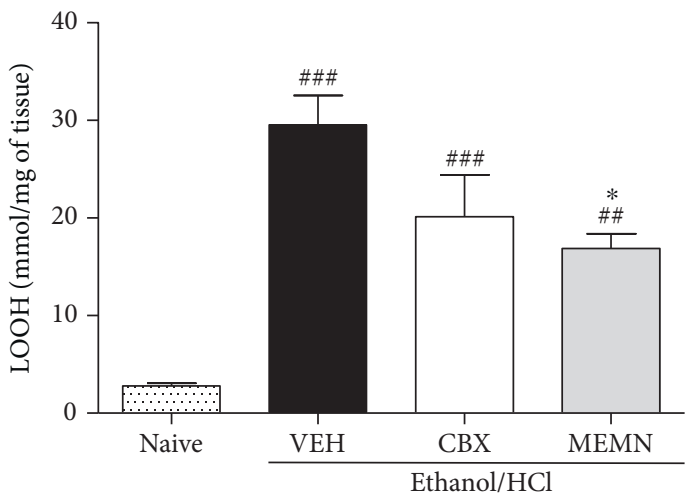

(c)

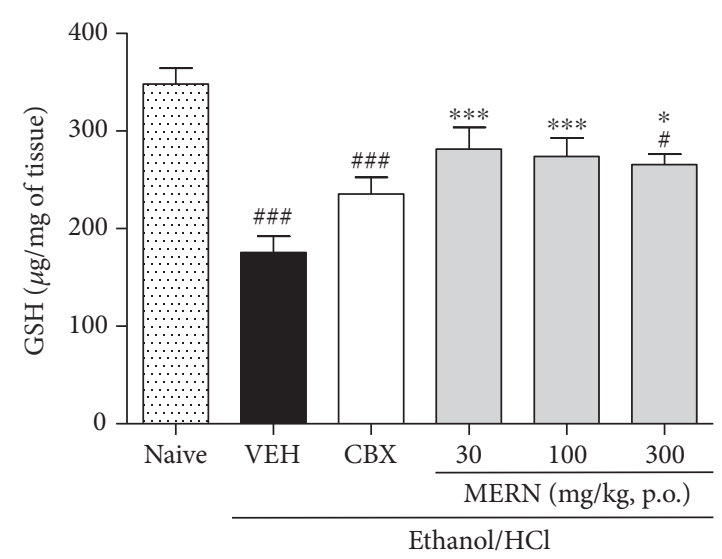

(b)

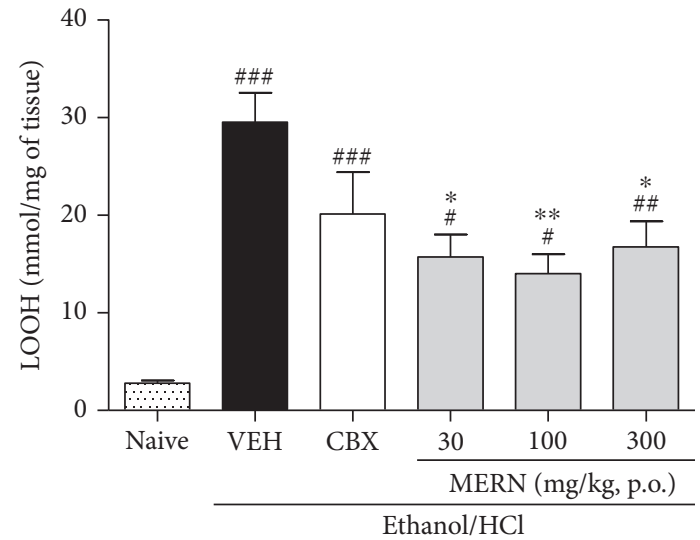

(d)

FIGURE 5: Effects of MEMN (300 mg/kg, p.o., (a) and (c)) and MERN (30-300 mg/kg, p.o., (b) and (d)) on lipoperoxides (LOOH) and reduced glutathione (GSH) levels on acidified ethanol-ulcerated tissue. The results are expressed as mean \pm SEM $(n=6)$. Statistical comparison was performed using one-way analysis of variance (ANOVA) followed by Bonferroni's test. ${ }^{\#} p<0.05,{ }^{\# \#} p<0.01$, and ${ }^{\# \# \#} p<0.001$ versus nonulcerated group (naïve). ${ }^{*} p<0.05,{ }^{* *} p<0.01$, and ${ }^{* * *} p<0.001$ versus vehicle group (VEH, water, $10 \mathrm{~mL} / \mathrm{kg}$ ). CBX: carbenoxolone (100 mg/kg, p.o.).

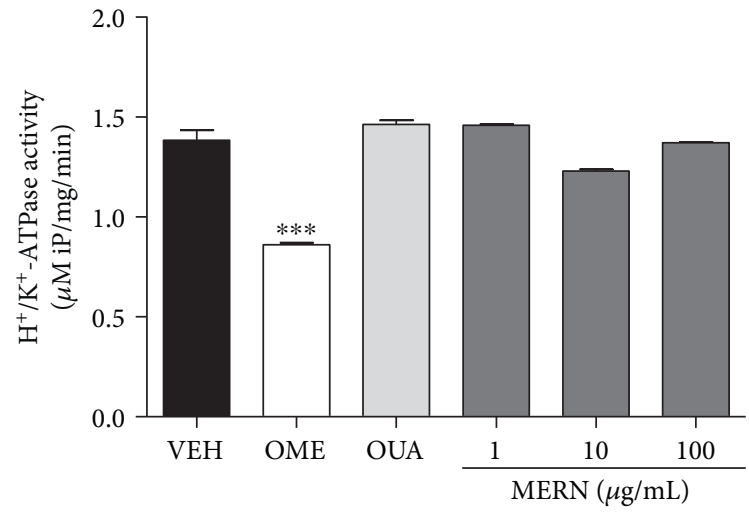

(a)

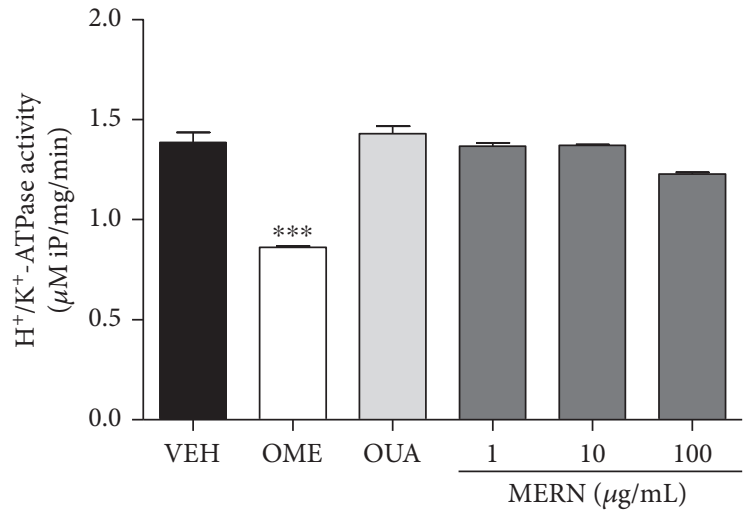

(b)

Figure 6: Effects of MEMN (1-100 $\mu \mathrm{g} / \mathrm{mL}$, (a)) and MERN (1-100 $\mu \mathrm{g} / \mathrm{mL}$, (b)) on in vitro $\mathrm{H}^{+} / \mathrm{K}^{+}$-ATPase activity. The results are expressed as mean \pm SEM, in triplicated experiments. Statistical comparison was performed using one-way analysis of variance (ANOVA) followed by Bonferroni's test. ${ }^{* * *} p<0.001$ versus vehicle group $(\mathrm{VEH})$. OME $=$ omeprazole $\left(\mathrm{H}^{+} / \mathrm{K}^{+}\right.$-ATPase inhibitor, $\left.34.5 \mu \mathrm{g} / \mathrm{mL}\right) . \mathrm{OUA}=\mathrm{ouabain}$ $\left(\mathrm{Na}^{+} / \mathrm{K}^{+}\right.$-ATPase inhibitor, $\left.72.8 \mu \mathrm{g} / \mathrm{mL}\right)$. 
The proton pump inhibitors (PPIs) are a pivotal class of drugs on the ulcer and gastroesophageal reflux disease therapy, although their long-term use carries the risk of several side effects that should be considered [9]. In contrast, MEMN (Figure 6(a)) or MERN (Figure 6(b)) did not change the in vitro $\mathrm{H}^{+} / \mathrm{K}^{+}$-ATPase activity, supporting the hypothesis that both extracts exert gastroprotection without altering proton pump function. Expectedly, omeprazole $(34.5 \mu \mathrm{g} /$ $\mathrm{mL})$, but not ouabain $(72.8 \mu \mathrm{g} / \mathrm{mL})$, inhibited the in vitro $\mathrm{H}^{+} / \mathrm{K}^{+}$-ATPase activity by $37.54 \%$, when compared to vehicle $(1.38 \pm 0.05 \mu \mathrm{mol} \mathrm{iP} / \mathrm{mg} / \mathrm{min})$. These findings reinforce that the studied berries constitute a promising source of natural products with potential complementary use in the current therapy, acting in a different way from the most conventional antiulcer drugs in clinical practice.

\section{Conclusion}

Taking together, the results from this study are promising and confirmed that the methanolic extracts obtained from the fruits of $M$. nigra or $R$. niveus concentrate on phenolic compounds, which can ensure their antioxidant and in turn gastroprotective potential.

\section{Conflicts of Interest}

The authors declare that there is no conflict of interest regarding the publication of this article.

\section{References}

[1] P. B. Yazbek, A. B. Trindade, C. M. Chin, and J. L. Dos Santos, "Challenges to the treatment and new perspectives for the eradication of Helicobacter pylori," Digestive Diseases and Sciences, vol. 60, no. 10, pp. 2901-2912, 2015.

[2] J. Y. Lau, A. Barkun, D. M. Fan, E. J. Kuipers, Y. S. Yang, and F. K. Chan, "Challenges in the management of acute peptic ulcer bleeding," Lancet, vol. 381, no. 9882, pp. 2033-2043, 2013.

[3] J. L. Goldstein, "Challenges in managing NSAID-associated gastrointestinal tract injury," Digestion, vol. 69, no. 1, pp. 2533, 2004

[4] L. Laine, K. Takeuchi, and A. Tarnawki, "Gastric mucosal defense and cytoprotection: bench to bedside," Gastroenterology, vol. 135, pp. 41-60, 2008.

[5] R. O. Nneli, W. C. Nwafia, and J. O. Orji, "Diets/dietary habits and certain gastrointestinal disorders in the tropics: a review," Nigerian Journal of Physiological Sciences, vol. 22, no. 1-2, pp. 1-13, 2010.

[6] E. U. Nwose and K. C. Yee, "Drug-disease interactions: narrative review of aspirin in gastric ulcer," Expert Opinion on Drug Metabolism \& Toxicology, vol. 12, no. 9, pp. 1081-1087, 2016.

[7] A. Franke, S. Teyssen, and M. V. Singer, "Alcohol-related diseases of the esophagus and stomach," Digestive Diseases, vol. 23, no. 3-4, pp. 204-213, 2006.

[8] M. P. Dore, G. M. Pes, G. Bassotti, and P. Usai-Satta, "Dyspepsia: when and how to test for Helicobacter pylori infection," Gastroenterology Research and Practice, vol. 2016, Article ID 8463614, 9 pages, 2016.
[9] L. Y. Yu, L. N. Sun, X. H. Zhang et al., "A review of the novel application and potential adverse effects of proton pump inhibitors," Advances in Therapy, vol. 34, 2017.

[10] N. Kangwan, J. M. Park, E. H. Kim, and K. B. Hahm, "Quality of healing of gastric ulcers: natural products beyond acid suppression," World Journal of Gastrointestinal Pathophysiology, vol. 5, pp. 40-47, 2014.

[11] N. Deighton, R. Brennan, C. Finn, and H. V. Davies, "Antioxidant properties of domesticated and wild Rubus species," Journal of the Science of Food and Agriculture, vol. 80, pp. 1307-1313, 2000.

[12] M. Gundogdu, F. Muradoglu, R. I. Gazioglu Sensoy, and H. Yilmaz, "Determination of fruit chemical properties of Morus nigra L., Morus alba L. and Morus rubra L. by HPLC," Scientia Horticulturae, vol. 132, pp. 37-41, 2011.

[13] S. Skrovankova, D. Sumczynski, J. Mlcek, T. Jurikova, and J. Sochor, "Bioactive compounds and antioxidant activity in different types of berries," International Journal of Molecular Sciences, vol. 16, no. 10, pp. 24673-24706, 2015.

[14] Brasil. Ministério da Saúde. Direção de Administração e Finanças. Secretaria de Ciência, Tecnologia e Insumos Estratégicos, "RENISUS - Relação Nacional de Plantas Medicinais de Interesse ao SUS," 2009. 1 p. April 2017, http://portalarquivos. saude.gov.br/images/pdf/2014/maio/07/renisus.pdf.

[15] V. Cechinel Filho and R. A. Yunes, "Estratégias para a obtenção de compostos farmacologicamente ativos a partir de plantas medicinais: conceitos sobre modificação estrutural para otimização da atividade," Química Nova, vol. 21, no. 1, pp. 99-105, 1998.

[16] A. Arnous, D. P. Makris, and P. Kefalas, "Effect of principal polyphenolic components in relation to antioxidant characteristics of aged red wines," Journal of Agricultural and Food Chemistry, vol. 49, pp. 5736-5742, 2001.

[17] A. Arvouet-Grand, B. Vennat, A. Pourrat, and P. Legret, "Standardization of propolis extract and identification of principal constituents," Journal de Pharmacie de Belgique, vol. 49, no. 6, pp. 462-468, 1994.

[18] L. M. Da Silva, T. Boeing, L. B. Somensi et al., "Evidence of gastric ulcer healing activity of Maytenus robusta Reissek: in vitro and in vivo studies," Journal of Ethnopharmacology, vol. 175, pp. 75-85, 2015.

[19] A. P. Beber, P. de Souza, T. Boeing et al., "Constituents of leaves from Bauhinia curvula Benth. exert gastroprotective activity in rodents: role of quercitrin and kaempferol," Inflammopharmacology, 2017, in press.

[20] Z. Y. Jiang, J. V. Hunt, and S. P. Wolff, "Ferrous ion oxidation in the presence of xylenol orange for detection of lipid hydroperoxide in low density lipoprotein," Analytical Biochemistry, vol. 202, pp. 384-389, 1992.

[21] J. Sedlack and R. H. Lindsay, "Estimation of total, proteinbound, and nonprotein sulfhydryl groups in tissue with Ellman's reagent," Analytical Biochemistry, vol. 24, no. 1, pp. 192-205, 1968.

[22] K. Kubo, H. Uehara, T. Kubota et al., "Effects of ranitidine on gastric vesicles containing $\mathrm{H}^{+}, \mathrm{K}^{+}$-adenosine triphosphatase in rats," Scandinavian Journal of Gastroenterology, vol. 30, pp. 944-951, 1995.

[23] M. A. Quadri and R. K. Srivastava, "Micro-determination of inorganic phosphorus and alkaline phosphatase activity in biological fluids," Archiv für Experimentelle Veterinärmedizin, vol. 34 , no. 5, pp. 667-672, 1980. 
[24] S. N. Jimenez-Garcia, R. G. Guevara-Gonzalez, R. MirandaLopez, A. A. Feregrino-Perez, I. Torres-Pacheco, and M. A. Vazquez-Cruz, "Functional properties and quality characteristics of bioactive compounds in berries: biochemistry, biotechnology, and genomics," Food Research International, vol. 54, no. 1, pp. 1195-1207, 2013.

[25] R. Z. Feng, Q. Wang, W. Z. Tong et al., "Extraction and antioxidant activity of flavonoids of Morus nigra," International Journal of Clinical and Experimental Medicine, vol. 8, no. 12, pp. 22328-22336, 2015.

[26] M. Fritsch, A. Bohn, F. Kuhn, J. Scapinello, and J. Dal Magro, "Caracterização da atividade antioxidante de frutas silvestres da região Sul do Brasil," Anais do XX Congresso Brasileiro de Engenharia Química, vol. 1, no. 2, pp. 1-7, 2015.

[27] M. Özgen, S. Serçe, and C. Kaya, "Phytochemical and antioxidant properties of anthocyanin-rich Morus nigra and Morus rubra fruits," Scientia Horticulturae, Turquia, vol. 119, no. 3, pp. 275-279, 2009.

[28] A. M. Pawlowska, W. Oleszek, and A. Braca, "Quali-quantitative analyses of flavonoids of Morus nigra L. and Morus alba L. (Moraceae) fruits," Journal of Agricultural and Food Chemistry, vol. 56, no. 9, pp. 3377-3380, 2008.

[29] S. H. Fang, Y. C. Hou, and P. D. L. Chao, "Pharmacokinetic and pharmacodynamic interactions of morin and cyclosporine," Toxicology and Applied Pharmacology, vol. 205, no. 1, pp. 65-70, 2005.

[30] A. C. Jacques and R. C. Zambiazi, "Fitoquímicos em amorapreta (Rubus spp)," Semina: Ciências Agrárias, vol. 32, no. 1, pp. 245-260, 2011.

[31] W. Mullen, J. McGinn, M. E. Lean et al., "Ellagitannins, flavonoids, and other phenolics in red raspberries and their contribution to antioxidant capacity and vasorelaxation properties," Journal of Agricultural and Food Chemistry, vol. 50, pp. 51915196, 2002.

[32] G. J. McDougall, H. A. Ross, M. Ikeji, and D. Stewart, "Berry extracts exert different antiproliferative effects against cervical and colon cancer cells grown in vitro," Journal of Agricultural and Food Chemistry, vol. 56, pp. 3016-3023, 2008.

[33] H. A. Ross, G. J. McDougall, and D. Stewart, “Antiproliferative activity is predominantly associated with ellagitannins in raspberry extracts," Phytochemistry, vol. 68, pp. 218-228, 2007.

[34] S. Zafra-Stone, T. Yasmin, M. Bagchi, A. Chatterjee, J. A. Vinson, and D. Bagchi, "Berry anthocyanins as novel antioxidants in human health and disease prevention," Molecular Nutrition \& Food Research, vol. 51, no. 6, pp. 675-683, 2007.

[35] E. Sangiovanni, U. Vrhovsek, G. Rossoni et al., "Ellagitannins from Rubus berries for the control of gastric inflammation: in vitro and in vivo studies," PLoS One, vol. 8, no. 8, article e71762, 2013.

[36] J. H. Nam, H. J. Jung, J. Choi, K. T. Lee, and H. J. Park, “The anti-gastropathic and anti-rheumatic effect of niga-ichigoside F1 and 23-hydroxytormentic acid isolated from the unripe fruits of Rubus coreanus in a rat model," Biological \& Pharmaceutical Bulletin, vol. 29, no. 5, pp. 967-970, 2006.

[37] S. J. Kim, H. J. Lee, B. S. Kim et al., "Antiulcer activity of anthocyanins from Rubus coreanus via association with regulation of the activity of matrix metalloproteinase-2," Journal of Agricultural and Food Chemistry, vol. 59, no. 21, pp. 11786-11793, 2011.

[38] E. Espada-Bellido, M. Ferreiro-González, C. Carrera, M. Palma, C. G. Barroso, and G. F. Barbero, "Optimization of the ultrasound-assisted extraction of anthocyanins and total phenolic compounds in mulberry (Morus nigra) pulp," Food Chemistry, vol. 219, pp. 23-32, 2017.

[39] M. H. Farzaei, M. Abdollahi, and R. Rahimi, "Role of dietary polyphenols in the management of peptic ulcer," World Journal of Gastroenterology, vol. 21, no. 21, pp. 6499-6517, 2015.

[40] K. S. Mota, G. E. Dias, M. E. Pinto et al., "Flavonoids with gastroprotective activity," Molecules, vol. 14, no. 3, pp. 979-1012, 2009.

[41] F. Schlickmann, L. Mota da Silva, T. Boeing et al., "Gastroprotective bio-guiding study of fruits from Mimusops balata," Naunyn-Schmiedeberg's Archives of Pharmacology, vol. 388, no. 11, pp. 1187-1200, 2015.

[42] M. de Barros, L. Mota da Silva, T. Boeing et al., "Pharmacological reports about gastroprotective effects of methanolic extract from leaves of Solidago chilensis (Brazilian arnica) and its components quercitrin and afzelin in rodents," Naunyn-Schmiedeberg's Archives of Pharmacology, vol. 389, no. 4, pp. 403-417, 2016.

[43] M. Oroian and I. Escriche, "Antioxidants: characterization, natural sources, extraction and analysis," Food Research International, vol. 74, pp. 10-36, 2015.

[44] M. Arfan, R. Khan, A. Rybarczyk, and R. Amarowicz, "Antioxidant activity of mulberry fruit extracts," International Journal of Molecular Sciences, vol. 13, no. 2, pp. 2472-2480, 2012.

[45] R. Caindan, L. Cairang, J. Pengcuo, and L. Tong, "Comparison of compounds of three Rubus species and their antioxidant activity," Drug Discoveries \& Therapeutics, vol. 9, no. 6, pp. 391-396, 2015.

[46] M. Ahmad, S. Masood, S. Sultana, T. B. Hadda, A. Bader, and M. Zafar, "Report: antioxidant and nutraceutical value of wild medicinal Rubus berries," Pakistan Journal of Pharmaceutical Sciences, vol. 28, no. 1, pp. 241-247, 2015.

[47] S. Pérez, R. Taléns-Visconti, S. Rius-Pérez, I. Finamor, and J. Sastre, "Redox signaling in the gastrointestinal tract," Free Radical Biology \& Medicine, vol. 104, pp. 75-103, 2017.

[48] S. V. Siegmund, S. Haas, and M. V. Singer, "Animal models and their results in gastrointestinal alcohol research," Digestive Diseases, vol. 23, no. 3-4, pp. 181-194, 2006.

[49] H. Chen, J. Pu, D. Liu et al., "Anti-inflammatory and antinociceptive properties of flavonoids from the fruits of black mulberry (Morus nigra L.)," PLoS One, vol. 11, no. 4, article e0153080, 2016.

[50] H. Yandrapu and J. Sarosiek, "Protective factors of the gastric and duodenal mucosa: an overview," Current Gastroenterology Reports, vol. 17, no. 6, p. 24, 2015.

[51] S. Kumardas and D. M. Vasudevan, "Alcohol-induced oxidative stress," Life Sciences, vol. 81, no. 3, pp. 177-187, 2007.

[52] Y. Naito, T. Takagi, O. Handa, and T. Yoshikawa, "Lipid hydroperoxide-derived modification of proteins in gastrointestinal tract," Sub-Cellular Biochemistry, vol. 77, pp. 137148, 2014.

[53] S. Aydin, O. Yilmaz, and Z. Gokçe, "Protective effect of Morus nigra L. (mulberry) fruit extract on the liver fatty acid profile of Wistar rats," Pakistan Journal Zoology, vol. 47, no. 1, pp. 255261, 2015. 


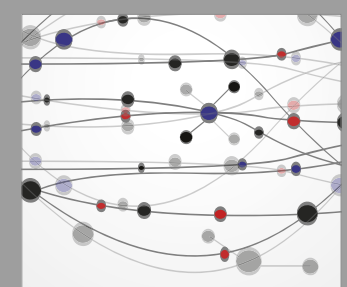

The Scientific World Journal
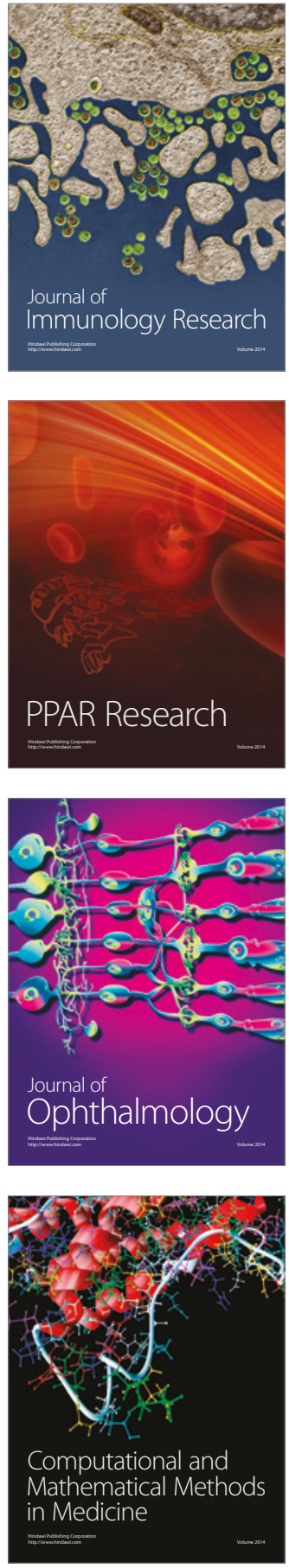

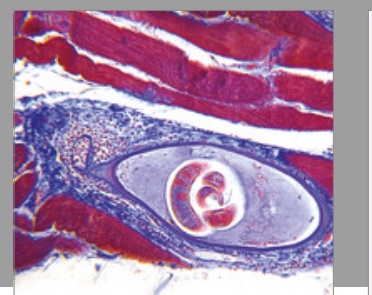

Gastroenterology Research and Practice
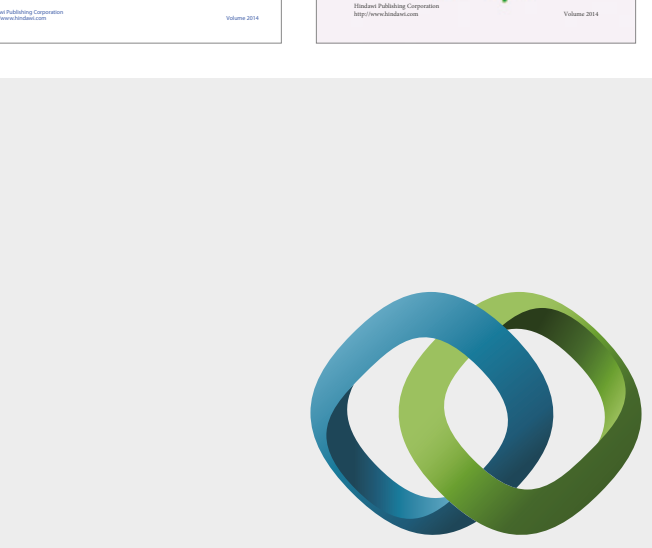

\section{Hindawi}

Submit your manuscripts at

https://www.hindawi.com
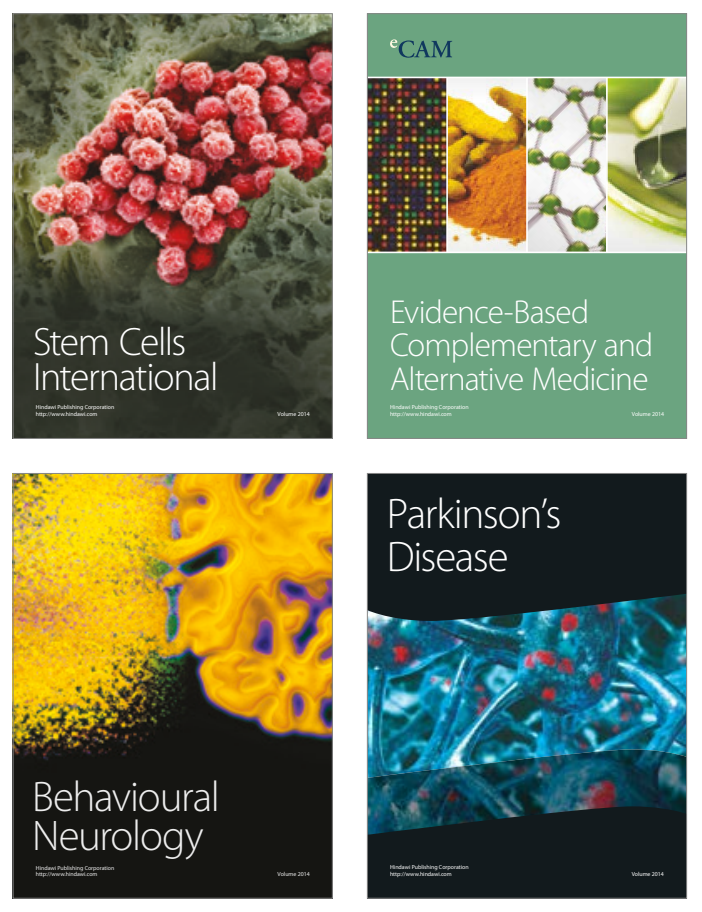
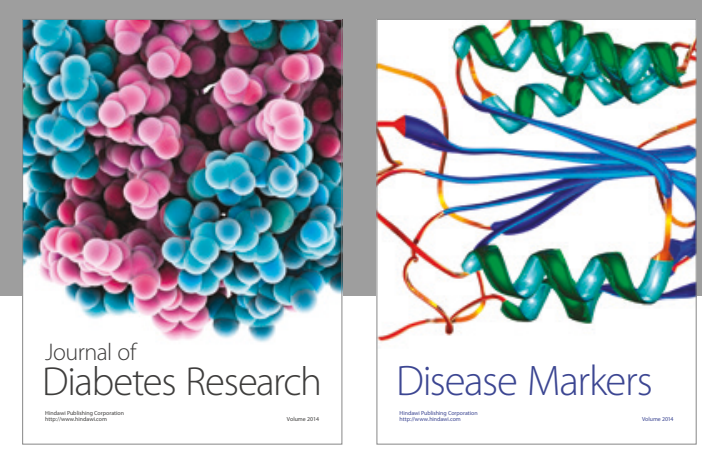

Disease Markers
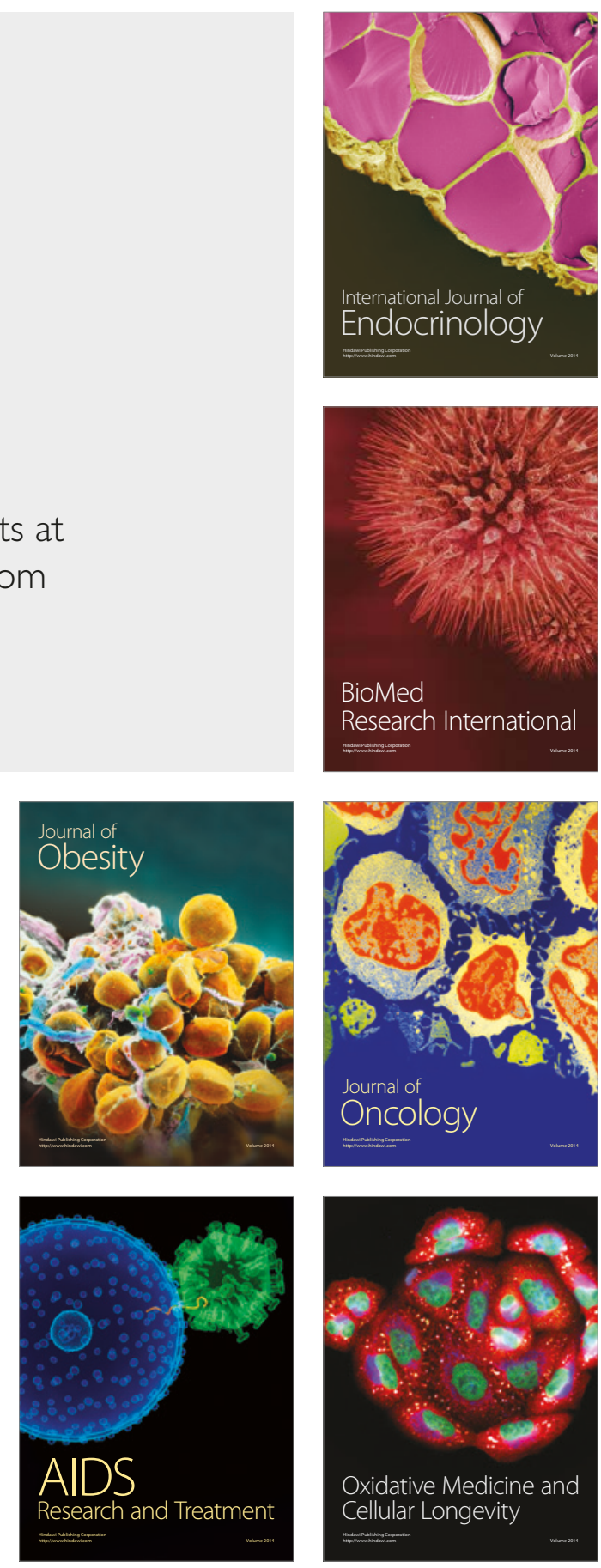